\title{
THE SYRIAN INFLUENCE OVER THE LATE ANTIQUE MOSAICS IN PHILIPPOPOLIS, THRACE
}

\section{IVO TOPALILOV}

UDC: $738.5(569.1: 497.234) " 02 / 05 "$

Original scientific paper

Manuscript received: 25. 11. 2015.

Revised manuscript accepted: 20. 03. 2016.

DOI: 10.1484/J.HAM.5.111336
I. Topalilov

The University of Shumen

Department of History and Archaeology

115 Universitetska Str

Shumen, 9712

Bulgaria

The paper deals with mosaic pavements from Philippopolis, the capital of the Late antique province of Thrace, which are supposed to be made after Syrian influence or by masters from that region. Three main types of examples are studied: 1). variations of standard geometric schemes which are repeated; 2). variations of motifs which are close parallels and 3). repetition of similar figural images. The examples come either from Early Christian buildings or richly decorated private dwellings. Despite the similarities between the mosaics of Philippopolis and those in Syria, some discrepancies also appear. It seems that the 'Syrian' influence was transmitted indirectly via the metropolitan masters, i. e. those from Constantinople, by following the decoration of a building in the provincial capital or home city or by immigrants and realized by the local masters. The metropolitan influence in Thrace, however, was enormous and spread in two ways: by simply copying the decoration of what was in the metropolis by the local patrons and the elite in Thrace and second one - through special imperial policy. And this is clearly visible in the second half of $4^{\text {th }} c$. at the earliest, but mostly after the decision of Theodosius I to settle in Constantinople when all of a sudden, Thrace from a remote province became part of the hinterland of the metropolis.

Key words: Philippopolis, mosaics, Syria, Antioch, geometric scheme

When one is dealing with the late antique mosaic pavements in Philippopolis he certainly will find in almost every study a note about the strong Syrian influence and its region on the pavements in the city. And this is not surprising since this was one of the biggest mosaic centers in the Eastern part of the Empire with traditions dated back as early as the Hellenistic period. ${ }^{1}$ The strong influence of this region continued later, in Roman and Late Antique period and was spread over some Asia Minor's centers as well as neighboring regions. The state of studying the problems of the mosaic pavements in Thrace, and Bulgaria as a whole, did not reach that level where all the workshops were identified for sure, and the mosaics were revealed. This is why, in most of studies the parallels of the mosaics from Thrace come at regions where the mosaic study is more advanced and therefore the influence of the latter over Thrace is accepted, in some case whatever the date of the parallels are. Philippopolis is not an exception.

In series of studies over the mosaic pavements and trends in Philippopolis, most of the scholars dealing with this topic advanced the idea of strong Syrian (or Eastern) influence, which in most cases was transmitted directly by Syrian masters who worked in Philippopolis as early as late $4^{\text {th }} \mathrm{c}$. It is believed that it was they who made most of the mosaic pavement on second floor of the Episcopal basilica, ${ }^{2}$ which is the third by its dimensions in the Balkan Peninsula, but also Domus Eirene, ${ }^{3}$ the so-called Residential complex, ${ }^{4}$ and probably the Synagogue (fig. 1).

In the next paragraphs I will make a brief summary of most revealing examples which are accepted as being made 'under Syrian influence' or Eastern masters which may be identified in various forms and especially three which are as follows: 1). variations of standard geometric schemes which are repeated; 2 ). variations of motifs which are close parallels and 3). repetition of similar figural images. In fact, by using them, one may identify to a certain degree the work of a particular mosaic workshop and the area which this workshop covered. ${ }^{5}$

Before starting the analyses it should be mentioned that the mosaic pavements in Philippopolis of the Late Antique period are characterized by their diversity of geometric schemes, motifs, and especially colours. As result of difference in taste various functions of the buildings can be assumed (especially when is dealt with religious buildings - Christian basilicas, martiria etc.), the rooms (especially when the case of the triclinium is meant), or the purpose of the mosaic pavement, the existing traditions in mosaic art which dated as early as $2^{\text {nd }} \mathrm{c}$. AD and which lasted through various workshops in the city at least until late $4^{\text {th }}$ c. etc.

\footnotetext{
${ }^{1}$ On the mosaics in Syria - see J. BALTY, Mosaïques antiques du Proche-Orient. Chronologie, iconographie, Interprétation (Centre de Recherches d'Histoire Ancienne 140), Paris, 1995; on the mosaics in Antioch - see D. LEVI, The Antioch Mosaic Pavements, vol. I-II, Roma, 1971; SH. CAMPBELL, The mosaics of Antioch, Subsidia Mediaevalia 15, Toronto, 1988; F. CIMOK, Antioch Mosaics: A Corpus, Istanbul, 20oo; L. BECKER \& CH. KONDOLEON (eds) The Arts of Antioch: Art Historical and Scientific Approach to Roman Mosaics and a Catalogue of the Worcester Art Museum Antioch Collection, Worcester, 2005. ${ }^{2}$ Е. КЕСЯКОВА, Мозайки от епископската базилика на Филипопол, in St. Stanev, V. Grigorov, V. Dimitrov (ed.), Studies in honour of Stefan Biyadzhiev, Sofia, 2011, p. 173-210.

3 M. BOSPACHIEVA, The Late antique building EIPHNH with mosaics from Philippopolis (Plovdiv, Southern Bulgaria), Archaeologia Bulgarica 2, 2003, p. 96-102; see also M. BOSPAČIEVA, Spätantike (frühchristliche) Denkmäler in Philippopolis (Plovdiv, Bulgarien), Mitteilungen zur Christlichen archäologie, 11, 2005, S. 39.

4 Е. КЕСЯКОВА, Мозайки от Резиденцията на Филипопол, Годишник на Регионалния Археологически музей-Пловдив, 11, 2009, с. 138.

${ }^{5}$ see the study of SH. CAMPBELL, Roman mosaic workshops in Turkey, American Journal of Archaeology, vol. 83, No. 3, 1979 , p. 287-292.
} 


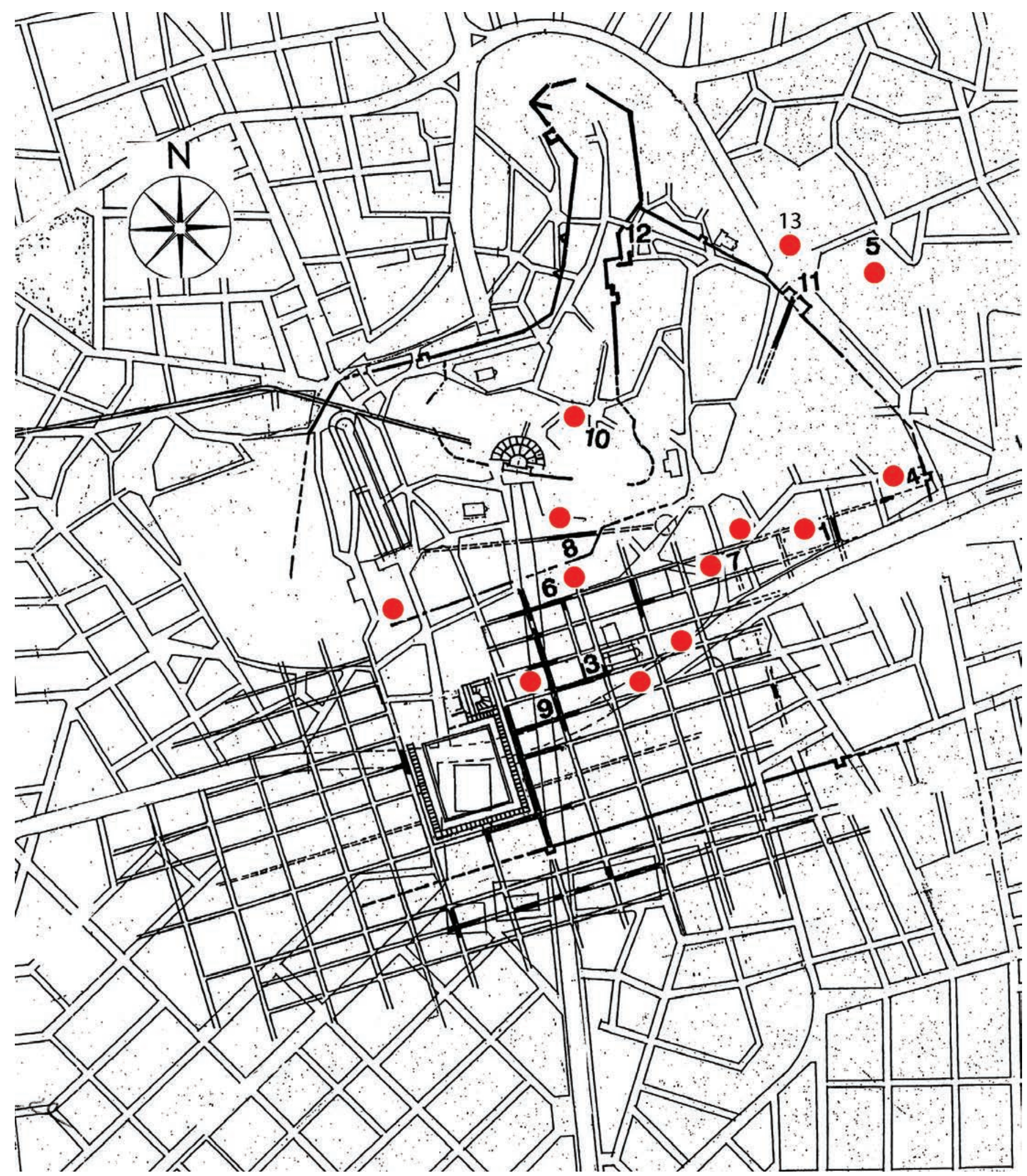

Fig. 1. The distribution of the mosaic pavements in LA Philippopolis

\section{THE USE OF ANALOGICAL GEOMETRIC SCHEMES}

The resemblance between the schemes used in Philippopolis and analogues found in mosaic pavements in Syria according to some scholars is good enough to claim such 'influence'. In fact, it is the most widely spread way to explain how they appeared in Thrace. The examples are several and they concern the geometric schemes used not only in the central panel, but also decorating the bordures. The latter, however, will be studied in the next paragraph accepting them more or less like motifs.

It is very often when studied a certain mosaic panel from Philippopolis to be given preference to parallels of similar or the same geometric scheme made by Eastern mosaic workshops and especially those in Antioch and Apameia. Less, but still existing are the parallels from Israel and Jordan. In those cases, it is only the formal reassemble of the geometric frame which was taken into consideration, regardless the 
actual date of the pavements which in most cases is even late than those in Philippopolis. In some cases, these parallels were broadened with parallels from the Aegean islands and Continental Greece. Even in those cases, the preference is given to the Eastern workshop as it will be revealed below.

Not all examples available will be studied since this is not the main aim of this work, but some more specific will be discussed, namely three cases. I believe they are good enough for the present study.

1). One of the panels which covered the south aisle of the earlier Episcopal basilica could be pointed out as one of the most characteristic examples in this aspect. It comprises the scheme of outlined orthogonal pattern of adjacent crosses and irregular octagons, forming oblong hexagons (DG pl 180 b- variant) (fig. 2) and its analogous examples from Apameia and Antioch, and the conclusion of G. Salies, ${ }^{6}$ led E. Kessjakova to the suggestion that this composition has Syrian origin. ${ }^{7}$ It should be noted, however, that the similarities between the panel in Philippopolis and those in Syria come to an end by the pure geometric frame. The colors and motifs used differ entirely. Thus, unlike the Syrian mosaics the crosses and octagons in Philippopolis are presented in blue light and outlined by white strand. They are filled with two - strand guilloche of white, orange and red, and circle and saltire quatrefoil, interlaced and inscribed in a circle respectively. The hexagons are filled with white peltae and silver salver in light blue or red.

In Antioch this geometric frame in variants is to be found in two places: in room 8 of Bath D and room 7 of Kaoussie Church, West Aisle. In the bath pavement which is dated to AD 300-325 the crosses also contain two-strand guilloche, but others are empty, the octagons have rosettes and geometric ornaments, and the hexagons - geometric motifs. ${ }^{8}$ On the other case, in Kaoussie Church, Martyrion of St. Babylas, which is dated to exactly to $\mathrm{AD}_{3} 87$ each of octagons contains a rosette with a cruciform flower, and the crosses are in fact meanders in two-strand guilloche and rainbow. ${ }^{9}$

Indeed, the geometric frame under question experienced a renaissance in Syria and the East in $5^{-6^{\text {th }}}$ c., ${ }^{10}$ but in the period when it was made in Philippopolis which is late $4^{\text {th }}$ c. or the time of Theodosius I, it was preferred by Italian and Northern Greek workshops and especially the ones in Thessalonica. It was of these two places where the geometric frame was spread over the West Balkan area, ${ }^{11}$ including Dardania. Not surprisingly, having in mind that the same frame was used in the decoration of the porticos in the palace of Galerius in Thessalonica, it is also found in Thrace from the beginning of $4^{\text {th }}$ c., i. e. at the same time as that one in Thessalonica. It is the case with the so-called 'mosaic on Graf Ignatiev Street' in Augusta Trajana (Stara Zagora).12

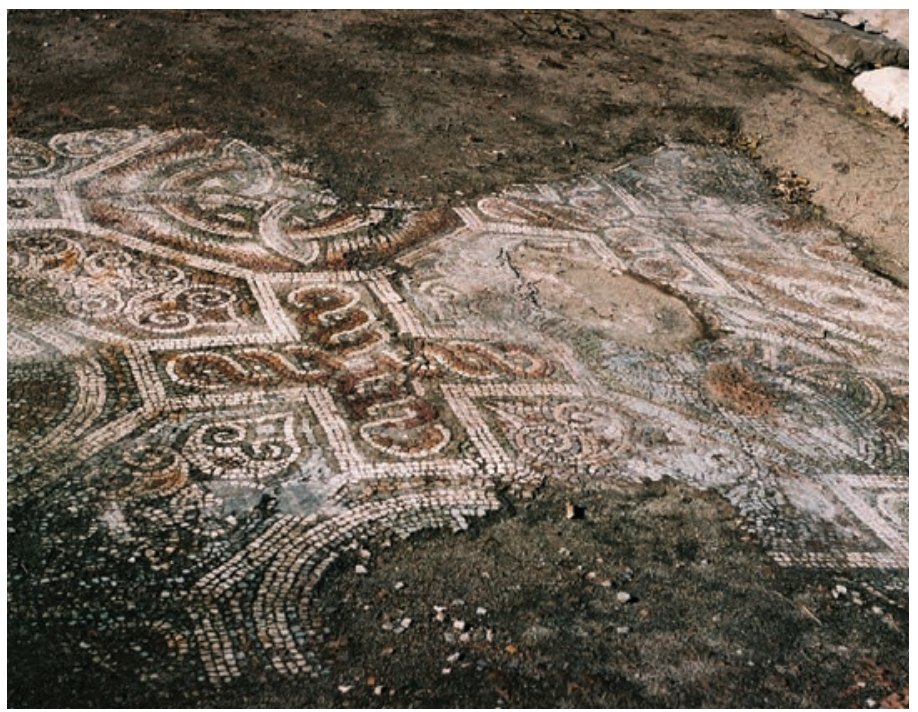

Fig. 2. The Episcopal basilica, First period, south aisle

This short summary shows that the mosaic in Philippopolis did not reassemble the examples cited in Syria. I am not going to discuss the variation of the geometric frame as it is by no means personal preference of the donator, but it seems that the differences between the mosaics in both regions are more than the similarities. Thus, graphically, the differences are to be found in the 'filling' of the individual geometric elements - octagons, hexagons, and crosses. The Syrian examples are mostly empty, and when they are filled, the ornaments used are quite different. The difference between the mosaics could be clearly attested in the presentation of the rosettes, which are more developed and lavishly decorated. ${ }^{13}$ And those specifics may be of help when trying to identify the mosaic workshop responsible for the mosaic in Philippopolis or the prototype which the master followed. It is without doubt that the master was not of Syrian origin, or at least did not follow the Syrian samples. More evidence is found in the range of colours used. What is more, the difference in the range of colours is a very distinctive difference between the mosaics.

Having in mind the mosaic in the Kaoussi Church which is from the same time as the mosaic in Philippopolis, it seems that the Syrian examples preferred a vast diversity of colours, and in addition to white and black several shades of gray, of red and of pink were very popular. ${ }^{14}$ They formed the famous for the Syrian mosaics rainbow-style. In sharp contrast is the colour range used in Philippopolis. It comprised mainly white, red with shades, yellow, dark and light blue. The mosaic in Philippopolis is also ornated by additional ornaments which filled the fields such as the so-called 'silver dish', peltae in variation, circle and saltire quatrefoil, interlaced and

\footnotetext{
${ }^{6}$ See for this G. SALIES, Untersuchungen zu den geometrischen Gliederungsschemata römischer Mosaiken, BJb 174, 1974 , S. 76.

7 E. КЕСЯКОВА, op. cit. (n. 2), c. 191.

${ }^{8}$ SH. CAMPBELL, op. cit (n. 1), p. 16.

9 Ibidem, p. 44, 96, fig. 19, pl. 131.

${ }^{10}$ See the examples cited in G. SALIES, op. cit. (n. 6) S. 133, №№ 358 - 359; $364-366$.

"Ibidem, S. 132, Nr.Nr. 346-348, 349; 133, Nr.Nr. 353-355; 134, № 360.

${ }^{12}$ For the mosaic see К. КАЛЧЕВ, Антични мозайки от Августа Траяна -Берое III-VI век, Известия на музеите в Югоизточна България, 24, 2оо9, c. 77 and most recently M. KAMISHEVA, Antique mosaics from Stara Zagora, Stara Zagora, 2015.

${ }^{13}$ see SH. CAMPBELL, op. cit. (n. 1) pl. 57-57.

${ }^{14}$ ibidem, p. 44.
} 


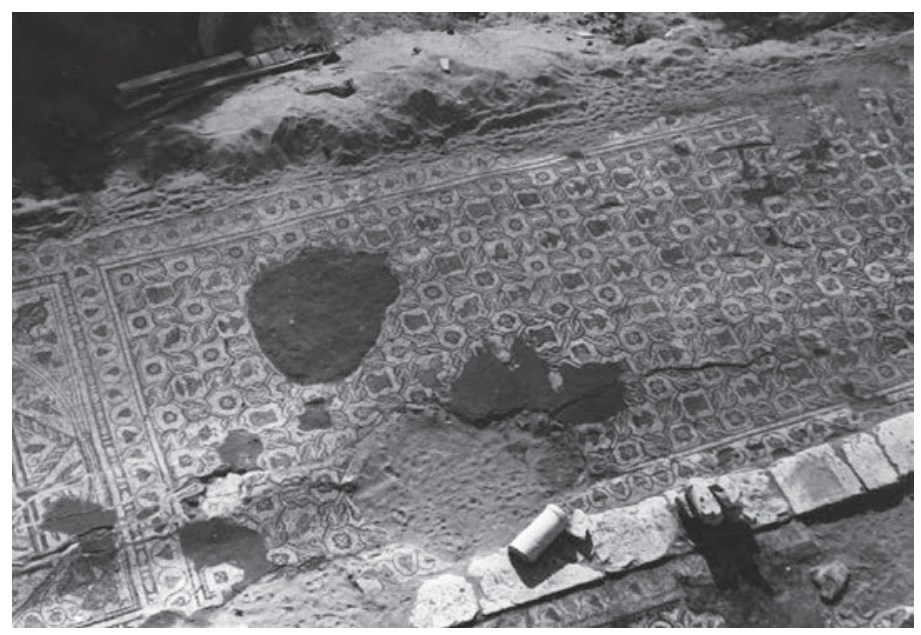

Fig. 3. The Episcopal basilica, Second period, Western panel, south aisle (after Е. Кесякова 2009, 178, fig. 4)

inscribed in a circle in the octagons etc. They are found in mosaics in Thessalonica ${ }^{15}$ and especially Constantinople. In fact, it is very likely that the construction of the Episcopal basilica is an imperial initiative ${ }^{16}$ which may have caused the involvement of mosaic masters coming from Constantinople and therefore metropolitan mosaic workshops.

All mentioned gives me the reason to put under question analogies proposed in the bibliography with Syria; it is more likely that the mosaic is made by metropolitan masters, but not from Syria.

2). The south aisle of the Episcopal basilica from the second period, the first and third panel, i. e. eastern and western, has similar decoration. They are filled in polychrome grid-pattern of Hercules' knots in interlooped asymmetrically shaded bands (DG pl. 254f). The fields within the concave squares are filled with birds, kantharos and baskets while the rest of the fields - stylized rosettes (fig. 3). ${ }^{17}$

The bounds are outlined in dark blue and filled with white, yellow and red rows, and yellow and two whites respectively. The space is in mixture and white and light yellow tesselae, the birds are of various types, but all of them outlined in dark blue. They are presented in variations of the combination of light blue, yellow, red, and white. The same is valid for the kantharoi. The baskets are outlined in dark blue with yellow and red tessalae and filled with flowers. The latter are of two types again outlined with dark blue and filled in white with red eyelet and yellow with red eyelet again. The rosettes are schematic with salient cross of dark blue and red florets (fig. 4).

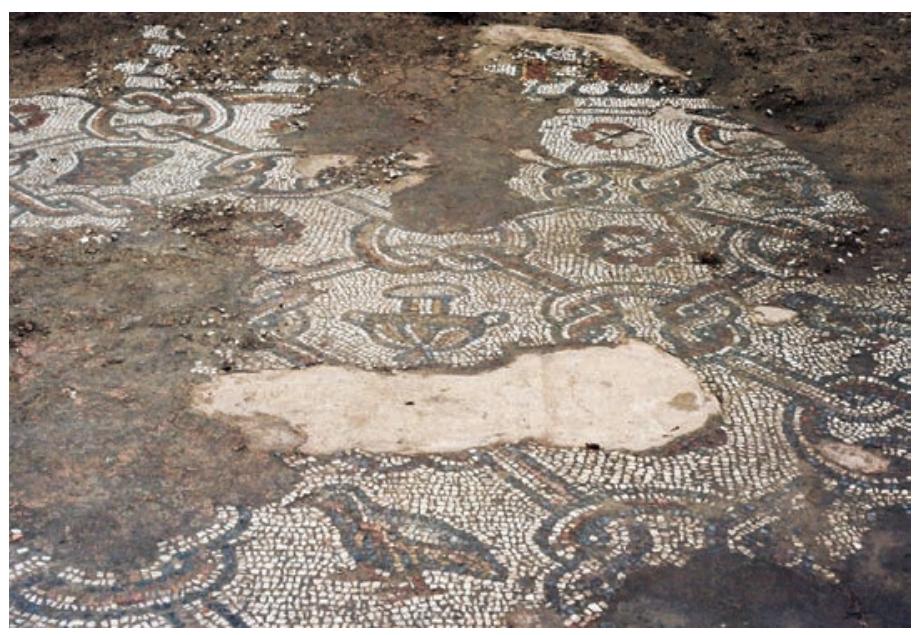

Fig. 4. The Episcopal basilica, Second period, Western panel, south aisle

The example cited is used as explicit evidence for the work of Eastern masters in the Balkans. ${ }^{18}$ The arguments are in two ways: the use of widely spread in Syria, Palestine and Lebanon motif of 'Heracles knot', and the close parallels of the mosaic with the panel in the southern aisle of the basilica at Skorpilovtzi and that one in a building, probably a basilica in Maroneia; it is said that the mosaic in Maroenia is certainly made by travelling Syrian mosaists. ${ }^{19}$ This conclusion finds also some arguments in the existence of a small eastern (Syrian?) community in Odessos, which is easily recognized by the epigraphic monuments, and the church at Dzanavara which shows some architectural features quite common in Syria. ${ }^{20}$ The parallels used for the mosaic in Skorpilivtzi which also refer to the mosaic in Philippopolis are mostly from Lebanon - the basilica in Halde (middle of $5^{\text {th }}$ c.), Zahrani ( $5^{\text {th }}$ c.), Auzei (second half of $5^{\text {th }}$ c.), and in Israel - Shumata (first half of $6^{\text {th }} c$.), Kursi (late $5^{\text {th }} /$ the beginning of $6^{\text {th }} c$. $)^{21}$ and Naharya $\left(6^{\text {th }} c .\right)^{22}$ Some more parallels are also available from the first half of $5^{\text {th }} \mathrm{c}$. in Marusinac and Kapljuč. ${ }^{23}$

It is obvious that before starting with the analysis all the mosaics which are dated later than the Philippopolis's one should be excluded form the list. The latter is dated in the second-third quarter of $5^{\text {th }} \mathrm{c}$. which means that all Israeli examples and those, closest to Philippopolis, viz. Maroneia and Shkorpilovtzi should not be included in such a study. Besides, it should be pointed out also the lack of the geometric frame used in the panels of Philippopolis among the mosaics in Antioch, Apameia and Aphrodisias.

\footnotetext{
${ }^{15}$ In a house of the first quartet of $5^{\text {th }}$ c. - P. ASSIMAKOPOULOU-ATZAKA, Syntagma ton palaiochristianikon psefidoton dapedon tes Ellados. III.

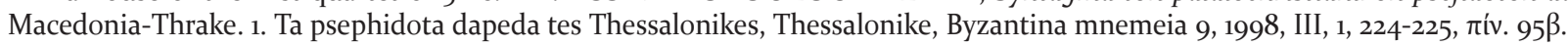

${ }^{16}$ For this - see I. TOPALILOV, The importance of the so-called 'Eastern Gate' complex for the Christians and Christianity in LA Philippopolis (in print).

${ }^{17}$ For full description of the panel - see M. BOSPAČIEVA, op. cit. (n. 3); Е. КЕСЯКОВA, op. cit. (n. 4).

${ }^{18}$ А. МИНЧЕВ, Две раннохристиянски мозайки с източни мотиви от Варненска област -в: Християнската идея в историята и културата на Европа, in: Материали от VIII лятна научна среща, посветена на 20оо-годишнината от рождението на Иисус Христос, Варна, 24-25 юни, 200о, София, 2001, с. 61.

${ }^{19}$ ibidem, c. 61.

${ }^{20}$ АЛ. МИНЧЕВ, Ранното християнство в Одесос и околностите му, Известия на Народния музей - Варна, кн. 22 /37/, 1986, стр.31-42.

${ }^{21}$ See V. TZAFARIS, The Early Christian Monastery at Kursi, in Ancient Churches revealed (ed. V. Tsafaris), Jerusalem, 1995 , p. 77.

${ }^{22}$ The mosaic and the church are dated to the time of Justinian I - see C. DAUPHIN, C., G. EDELSTEIN, The Byzantine church at Nahariya, in: Ancient Churches revealed (ed. V. Tsafaris), Jerusalem, 1995, 51-53.

${ }^{23}$ C. KORANDA, Geometrische Gliederungsschemata frühchristlicher Mosaiken in Bulgarien, JÖAI 1991/1992, Bd. 61, S.109; A. MИНЧЕВ, op. cit. (n. 18), c. 59.

${ }^{24}$ See for instance the basilica in Horvat Brahot - V. TSAFARIS, op. cit. (n. 21), pl. XV etc.

${ }^{25}$ ibidem, pl. XV-XVI.
} 


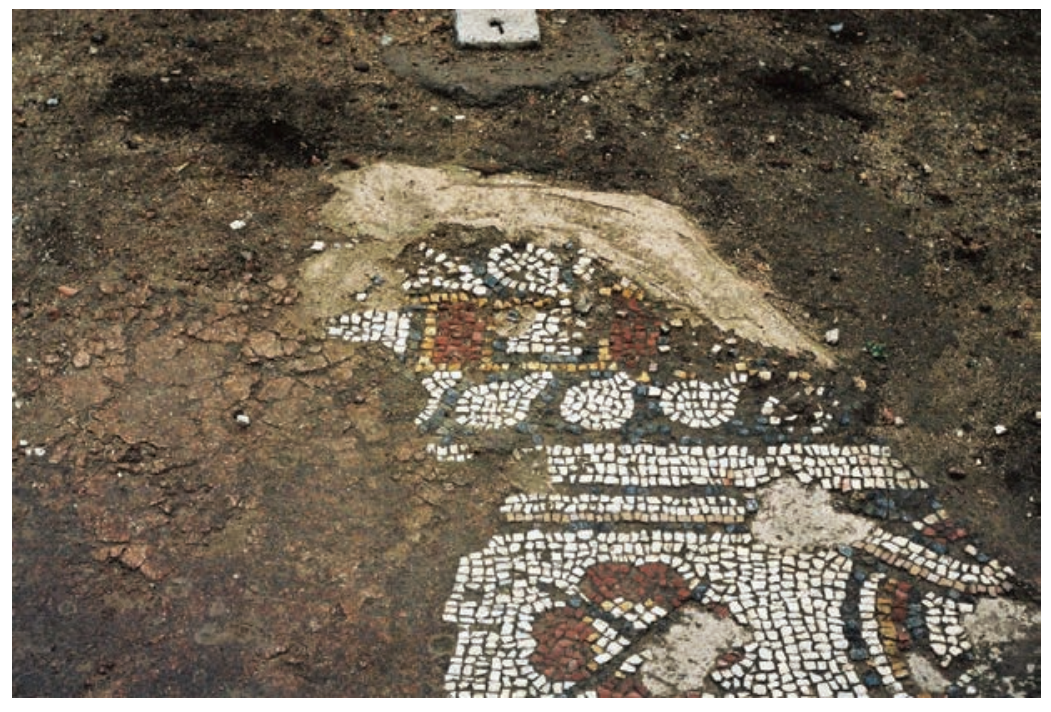

Fig. 5. The Episcopal basilica, Second period, Western panel, south aisle: the 'peach-shape' ornament

A striking contrast between the mosaic in Philippopolis and the aforementioned are the colours used. Thus, it seems that the warm nuances - red and in lighter shades, light yellow, light - blue, and rarely black were preferred, mostly in the geometric frame. Incidentally, some other colours such as shades of green may be used when birds ${ }^{24}$ and animals ${ }^{25}$ are depicted. The manner of presenting, the main accent of the mosaics which in Israel is the donator or commemorative inscription or the bordure, the various different variations of geometrisation which in some places is strict and well-defined, the image of animals and people as well as the different iconographic themes and especially motifs among which are the very specific rosettes ${ }^{26}$ are of great contrast to the mosaic in Philippopolis. ${ }^{27}$ This is why I believe that the parallels proposed in the literature are not the most accurate and would not reveal the origin of the masters who made the mosaic in Philippopolis.

In fact, it seems that in the mosaic panels in Philippopolis two main influences were interwoven: the metropolitan one, viz. Constantinople, and a northern Greek workshop, most probably from Thessalonica, but also some local preferences.

The metropolitan influence is clearly visible in the treatment of the whole mosaic in terms of iconography, the various elements, including the bordure, as well as the colour range. Thus, the sporadic use of red, and the most common preference of dark-blue colour especially for the contours is very characteristic for this workshop. As it is well known, the dark-blue colour is exceptionally rare in the Eastern examples, when they existed. On the contrary, the green colour which is found in Jordan, Syrian and Amphipolis is missing in these panels in Philippopolis; it is to be found only with the images of the birds.

The motifs are treated in different manner. Thus, the birds in the Philippopolitain mosaic which are presented

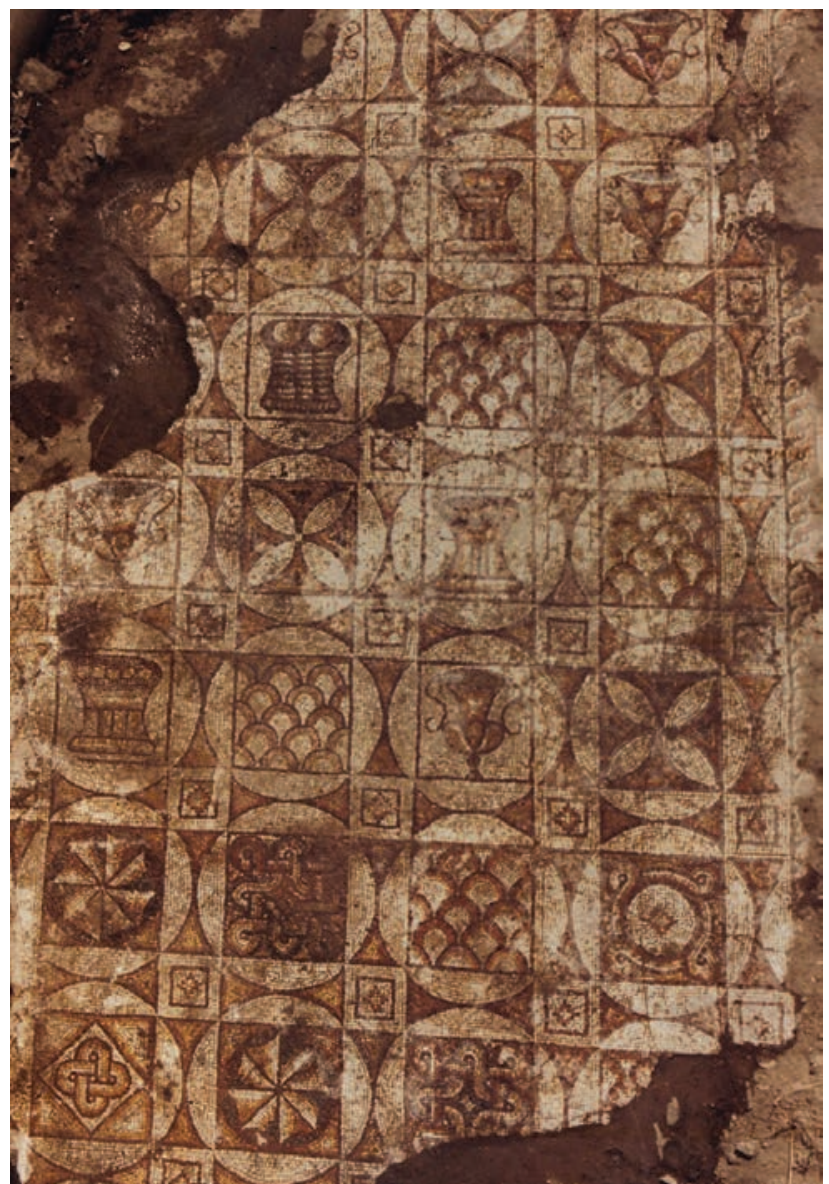

Fig. 6. The Episcopal basilica, Second period, nartex (after Е. Кесякова 2009, 196, fig. 26)

statically, schematically and outlined with a blue contour are in sharp contrast to the more 'vivid' birds in the Syrian mosaics, but also in Amphipolis, which are made in a more precise way, even as far as size if concerned. It seems that the motifs and the colour range from the Eastern workshops reached from one side Northern Greece in Thessalonica, Amphipolis, and Maroneia, and Constantinople from the other side.

The rosettes in the mosaic in Philippopolis were also treated in a schematic way even when compared with the most schematic rosettes in Antioch which are of two colours. ${ }^{28} \mathrm{~A}$ similar case, is the so called 'Ananeosis' dated also from the third quarter of $5^{\text {th }} \mathrm{c}^{29}$

As for the local influence, it is likely it deals with the very stylized presenting of birds, kantharoi, rosettes as well as other motifs which were not common such as the so-called by E. Kesjakova 'peach' or 'peach-shape' ornament (fig. 5). $3^{\circ}$ The depiction of kantharoi and baskets on the mosaic in this part of the basilica may be well linked to the liturgical needs which happened at this very place.

More examples like those discussed above are available where the only parallel or the most important ones are said

\footnotetext{
${ }^{26}$ See also R. HACHLILI,, Ancient Mosaic Pavements. Themes, Issues, and Trends. Selected studies, Brill, 2009; E. KITZINGER, Byzantinische Mosaiken in Israel (mit Einführender Text von E. Kitzinger), München, 1965.

${ }^{27}$ For such development of Jordan as integral part of the Near East - see M. PICCIRILLO, Byzantinische Mosaiken aus Jordanien, Wien, 1986, and in some sense Georgia - see M. ODIŠELI, Spätantike und frühchristliche Mosaike in Georgien, Wien, 1995.

${ }^{28}$ F. CIMOK, op. cit. (n. 1), p. 123.

${ }^{29}$ SH. CAMPBELL, op. cit. (n. 1), p. 27; pl. 81.

$3^{\circ}$ Е. КЕСЯКОВА, Op. cit (n. 2), c.179.
} 


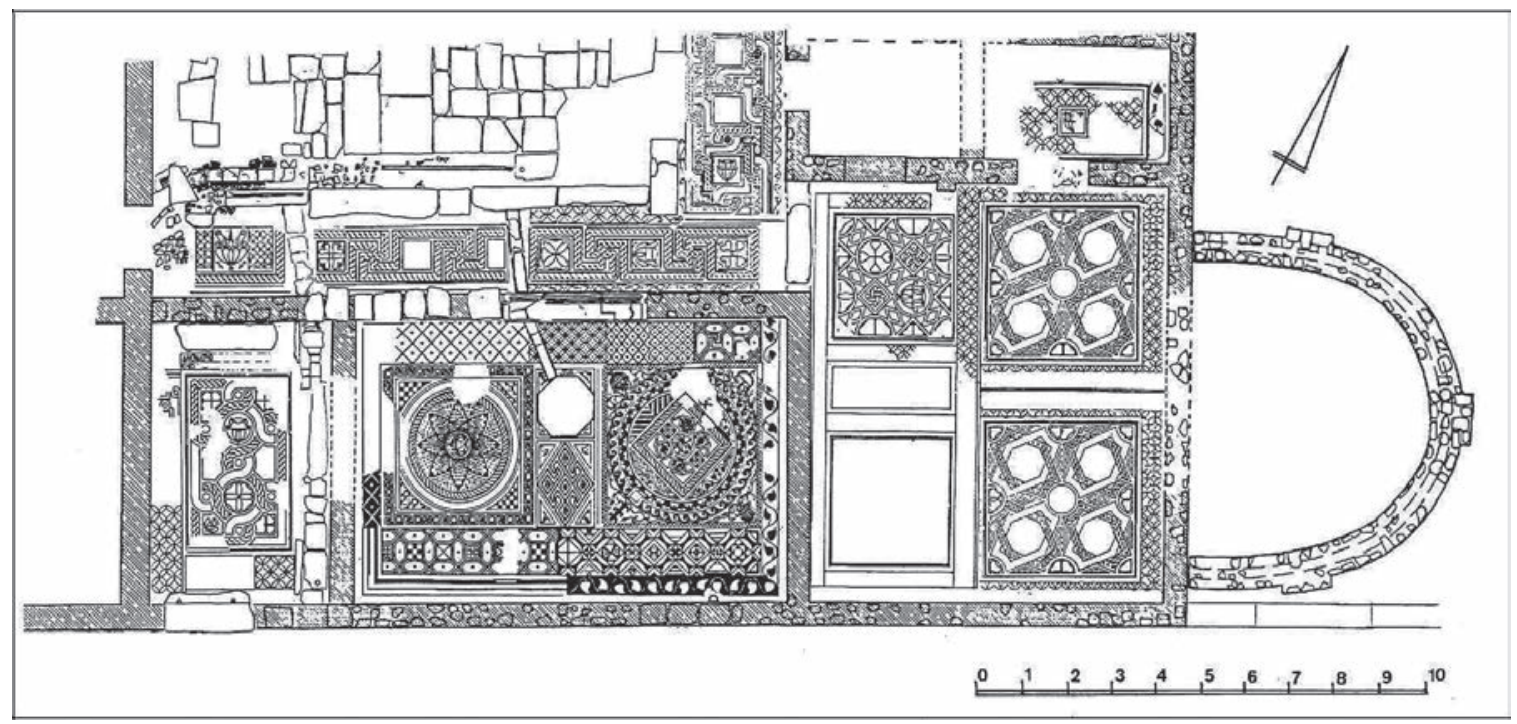

Fig. 9. The mosaics discovered in the Domus Eirene-(after M. Боспачиева, В. Коларова, Пловдив, град върху градовете. Филипопол-Пулпудева-Пълдин), София, 2014, 205)

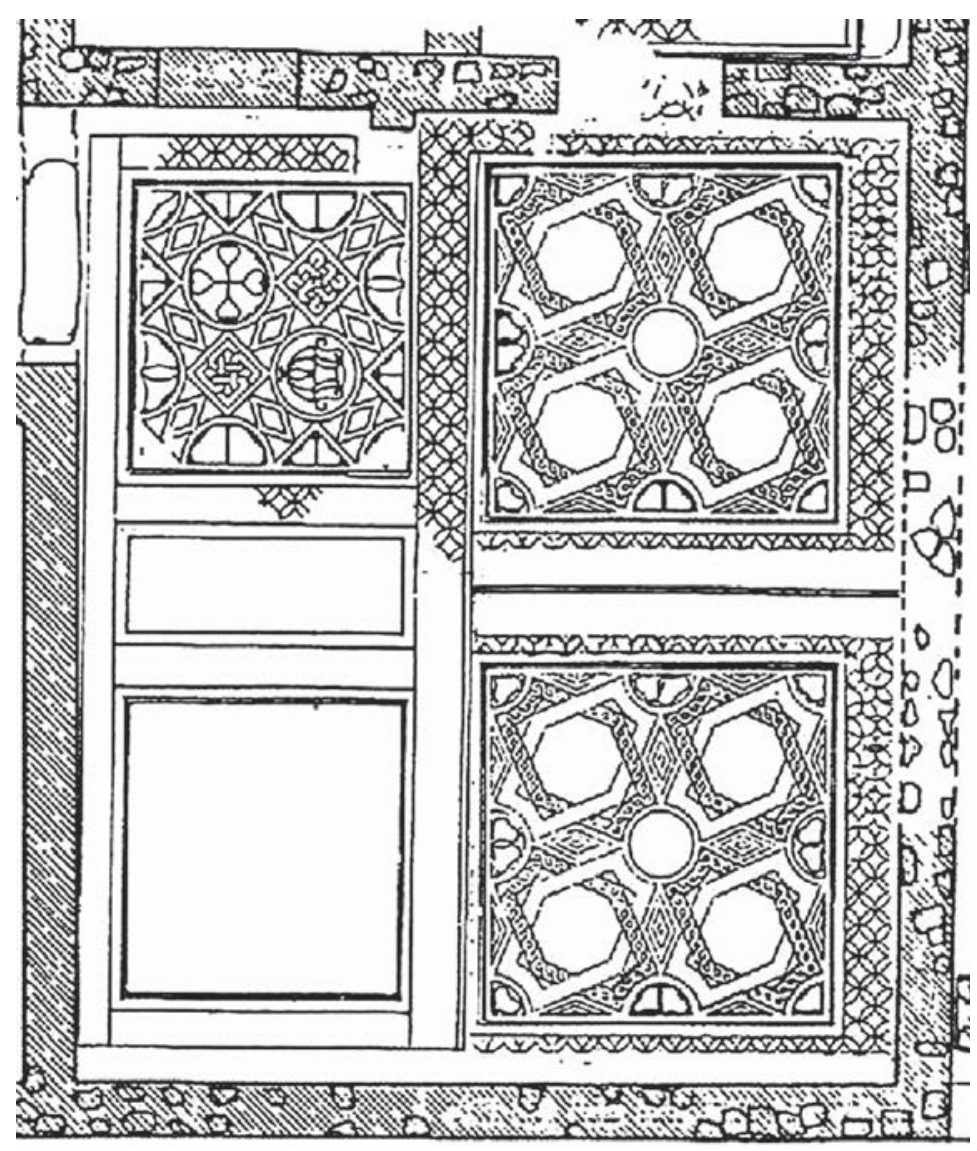

Fig. 7. - Domus Eirene, room 9 (after M. Боспачиева, В. Коларова, Пловдив, град върху градовете. Филипопол-Пулпудева-Пълдин), София, 2014, 207)

to come, from the Syrian mosaics; in those mosaics as we will see, the only common feature is the geometric scheme. A very good example of this is the panel in the so-called room $\mathrm{C}$ in the narthex which is filled with grid of bands with a square at the intersections bearing poised squares (DG pl 144e) (fig. 6), ${ }^{31}$ but also the panel in the south-eastern corner in room 9 in the EIPHNH building filled with interwoven scuta pat-

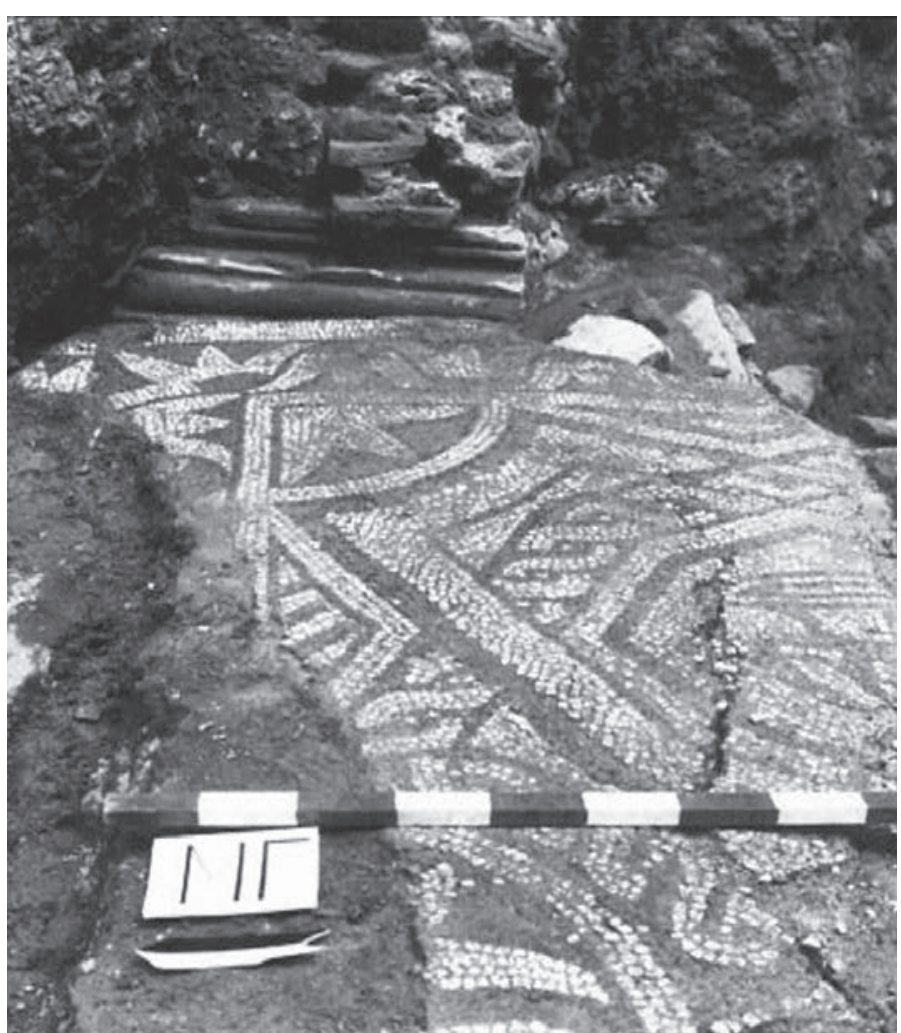

Fig. 8. - The mosaics of the Early Christian Martyrium

(after М. Боспачиева, В. Коларова, Пловдив, град върху градовете. Филипопол-Пулпудева-Пълдин), София, 2014, 280)

terns (DG pl. 153a)(fig. 7), etc. For the latter, which is also to be found in the Early Christian martyrium (fig. 8) 32 $^{2}$ only parallels based on the geometric scheme from Palestine and Syria, and more precisely Antioch, Apamea, and Magaba, are used. ${ }^{33}$ But, one could notice that the geometric schemes under consideration were very popular and even common in the mosaic pavements not only in the aforementioned mosaic centers, but also in closer geographically regions such as Thessalonica which were dated to the same period, and even in Philippopolis itself. This, it is to be found in

${ }^{31}$ Ibidem, c. 192.

${ }^{32}$ M. BOSPATCHIEVA, An Early Christian Martyrium from Philippopolis, Archaeologia Bulgarica 2, 2001, 63.

${ }_{33}$ M. BOSPACHEIVA, op. cit. ( n. 3) p. 101; M. BOSPAČIEVA, op. cit. (n. 3), S. 39. 
mosaic pavements dated from the second half of $4^{\text {th }} \mathrm{C}$. which is a product of a local workshop; ${ }^{34}$ the differences are, however, in the manner and the colour range used. Nonetheless, following strictly the main argument with the geometric scheme we would see that in Philippopolis the examples are earlier than those in Syria and without any doubt the latter has nothing to do with our cases.

The rest of the panel discussed above have also parallels in Greece, and mostly in Thessalonica as it is the case with the panel in the south-eastern corner in room 9 in Domus Eirene (fig. 9). ${ }^{35}$

\section{VARIATIONS OF MOTIFS}

In this paragraph mainly the geometric or other ornaments which filled the bordures, the space in the frames or between the main ornaments will be considered. Of those, only these which are said to be made by Syrian or Eastern masters or the prevailing parallels come from Syrian workshops will be discussed.

1). For some of the motifs and ornaments which filled the earlier bordures of the mosaic pavement in room 3 in Domus Eirene the only parallels cited in the literature come from Syria. What is more, as a parallel of the composition of mixed geometric and figural ornaments, the scholar pointed out only an example deriving form a villa located near Antioch. ${ }^{36}$ As for the motifs, we should take into consideration here the oblique swastika-meander embedded in a lozenge (DG pl. 196b) (fig. 10) as well as the grid pattern DG pl. 144e (fig. 11). It is said that in the first case, the pattern embodied a panel which separates the two emblemae and which parallel comes from Antioch. ${ }^{37}$ It should be noticed, however, that a panel filled with these ornaments is to be found also in room 1 , which in fact is the triclinium of House of the Boat of Psyches of Daphne suburb. $3^{8}$ In fact, this example provides also another parallel where the grid pattern DG pl. 144 e was used in a broad bordure as it is the case in Domus Eirene. The filling ornaments are lozenges and a cross inscribed in. It seems that the mosaic in Daphe is a very accurate parallel. The difference is, however, only in one thing, which is very important to me - the date; the mosaic in Philippopolis is dated from 8 os of $4^{\text {th }} \mathrm{c}$. while that one in Daphne - from 200-230 AD. 39

When the origin of the mosaic masters of room 3 is studied, one should take into account the assumption which up to now is the most plausible to me that the master in fact

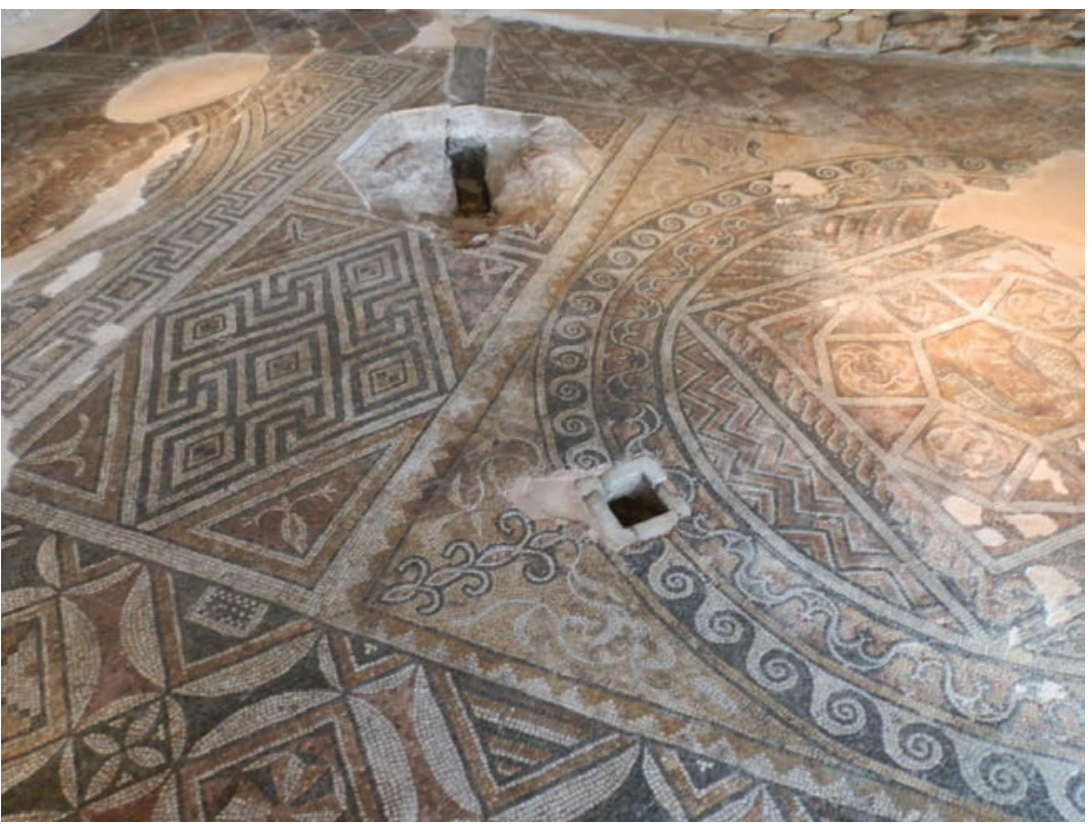

Fig. 10. Domus Eirene, room 3

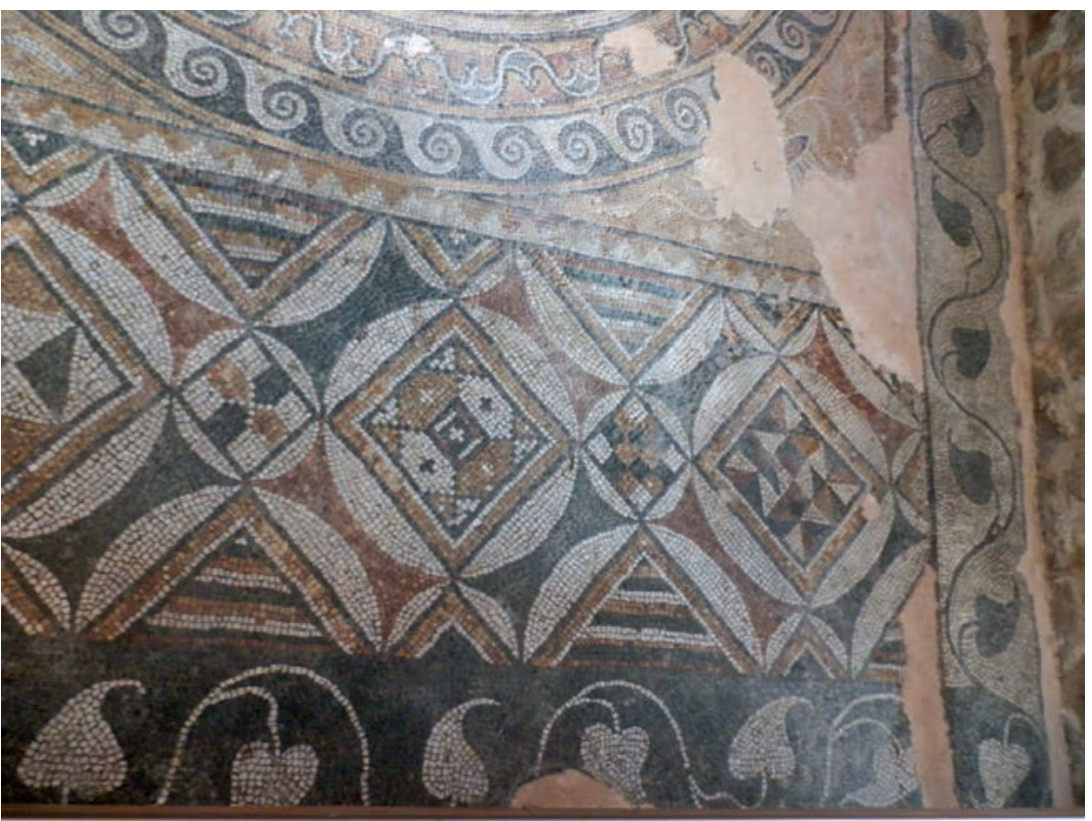

Fig. 11. Domus Eirene, room 3

came from the workshop of the island of Cos, or at least had been strongly influenced by that workshop or mainstream..$^{\circ}$ If this is so, we may suppose that the Syrian influence, if any, reached Philippopolis indirectly and through mediators who, however, transformed that mainstream. Up to now, the mosaic in room 3 in Domus Eirene is the mosaic in Philippopolis which is the closest to the Syrian examples. ${ }^{41}$

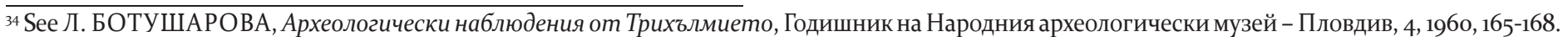
${ }^{35}$ M. BOSPACHIEVA, op. cit. (n. 3) p. 101.

${ }^{3}$ ibidem, 96.

37 ibidem, 99 with citation of J. LASSUS, L'église cruciforme de Kaoussie, in: Stillwell, R. (ed.) Antioch-on-the-Orontes. II, The excavations 1933-1936, Menasha/Wisconsin, 1938, pl. 33 d. Unfortunately, the latter was unavailable and that is why in this study will be used the other Corpora cited in note 1.

${ }^{38}$ D. LEVI, op. cit. (n. 1) pl. XXXV.

${ }^{39}$ For the description of the remains and mosaics - see ibidem, 167-191; L. BECKER \& CH. KONDOLEON, op. cit (n. 1) 154.

${ }^{40}$ The idea is advanced by V. Popova.

${ }^{41}$ In M. Bospachieva's article the parallels provided with Aegean and Continental Greece have in fact a much later date - M. BOSPACHIEVA, op. cit. (n. 3) p. 100.
} 


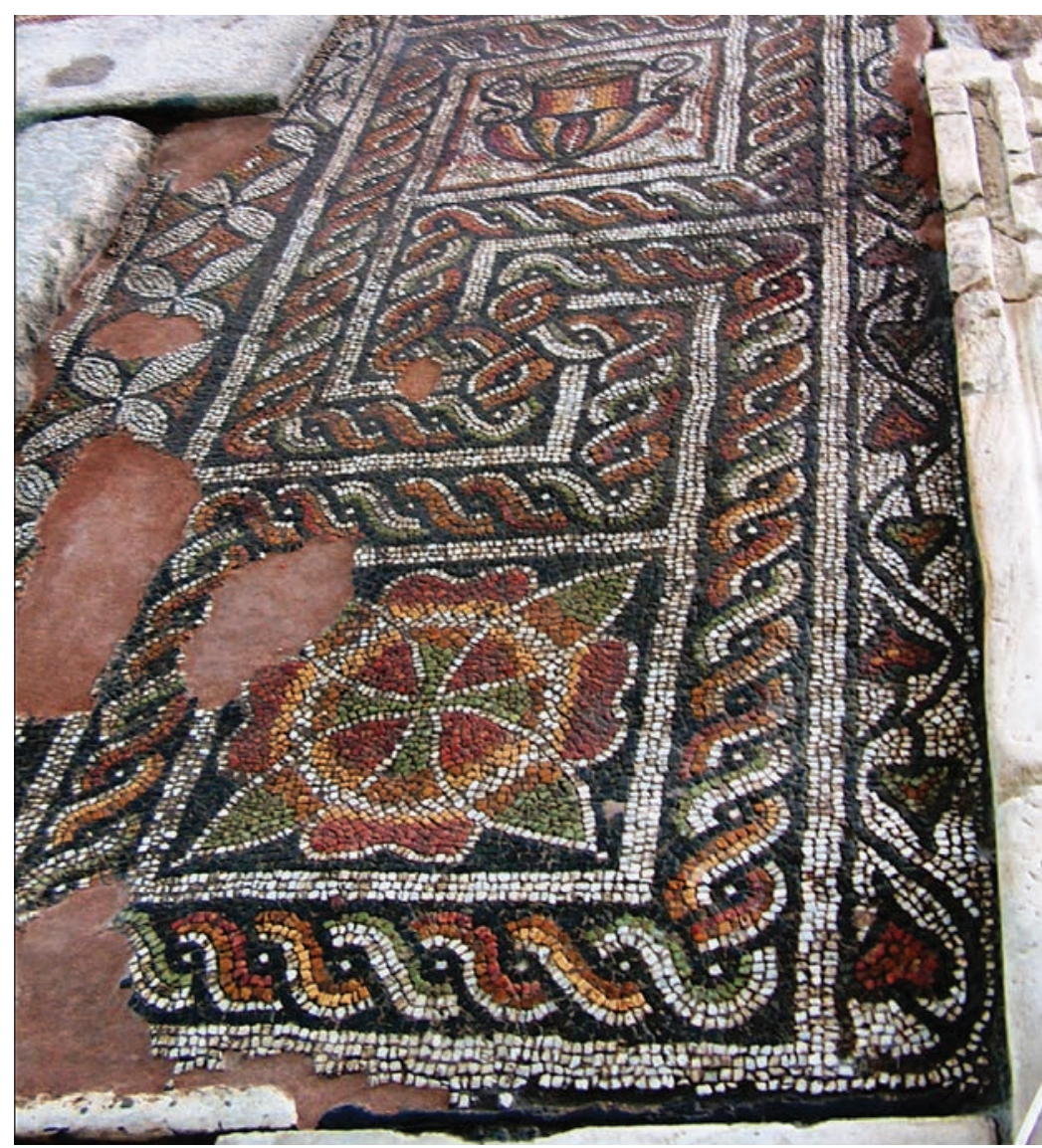

Fig. 12. Domus Eirene, Southern portico (after М. Боспачиева, В. Коларова, Пловдив, град върху градовете. Филипопол-Пулпудева-Пьлдин), София, 2014, 219)

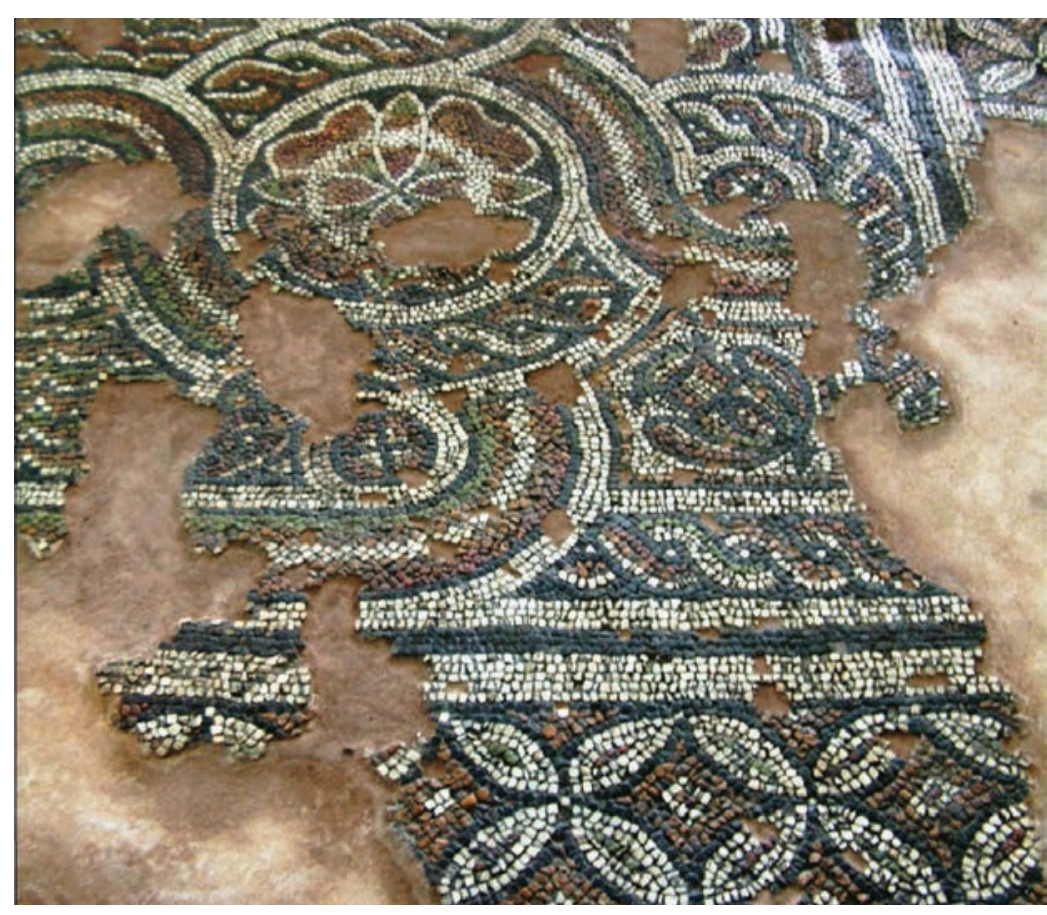

Fig. 13. Domus Eirene, the vestibule
It is therefore not surprising to find that the closest parallels of the other pattern, which is to be found in south-eastern half of southern border, come from Antioch, the villa from Daphne, from Daphne-Yakto as well as the church-martyrium at Kaoussi. ${ }^{42}$ The pattern, however, spread over the Greek island as well as Thessalonica. ${ }^{43}$

The combination of vases and rectangles in the way attested in the south portico of the Domus Eirene is also similar to those found in Antioch, but also in Thessalonica. ${ }^{44}$ The case with the motif of the western end of the south portico - DG pl. 22oc is similar, but this time with parallels in Antioch and Corinth. ${ }^{45}$

2). In some mosaics in Philippopolis one can find the type of a rosette with four large petals alternating with four slender leaves with a circle outlined in white. It is to be found in room 1 and the southern portico in Domus Eirene, the so-called 'Small basilica' and the so-called 'Residence'. It is most likely that the prototype derived from Antioch as the same type of rosette is used as early as the time of Trajan, ${ }^{46}$ and seems to have lasted at least until the middle of $4^{\text {th }} \mathrm{c} .47$ The variants of this type of rosette with four slender leaves which were bigger or smaller are to be found in Bath D in Antioch and in Domus Eirene in Philippopolis. The first variant is inscribed in a square in the southern portico (fig.12) with earlier parallels, ${ }^{48}$ while the second variant is to be found in the vestibule (fig. 13). ${ }^{49}$ Both variants belonged to mosaics from different periods - the earlier is dated roughly from the end of $4^{\text {th }} \mathrm{c}$. while the second - after the middle of $5^{\text {th }} \mathrm{c}$. It is obvious that most probably the prototypes come from Syria, but also some differences are clearly observed. Thus, in the Syrian items there is a white inner circle which almost filled up the small leaves, only their uppermost part was not covered. It is on the contrary in Philippopolis items - the inner white circle is thinner, with two or three rows of tessellates, while the Syrian is with seven-eight rows. The colour range also differs, and especially the preference is given to the green colour in Philippopolis examples. Unlike the Syrian ones, in Philippopolitain ones the lack of the 'eye' is also clearly observed. These specifics seem to me of significant differences. We can find, however, others examples which have more similarities with those of Philippopolis and which are closer geographically and chronologically to the latter. Thus, the variant with smaller leaves finds an exact parallel at the basilica 2 at Garmen, which is dated from the time of Theodosius I..$^{\circ}$ It is well established that this mosaic was made under the heavy influence of northern Greek workshops and especially those in Thessalonica. Therefore, I would assume the mosaic in Domus Ei-

\footnotetext{
42 ibidem, p. 100.

43 ibidem, p. 100.

44 ibidem, p. 100.

45 ibidem, p. 100.

${ }^{46}$ F. CIMOK, op. cit. (n. 1), p. 42.

${ }^{47}$ See for example Tarsus - F. CIMOK, op. cit. (n. 1), p. 144-147 and Bath D, room 8 - D. LEVI, op. cit. (n. 1) pl. CXVII, f.

${ }^{48}$ See the example in room 8 - SH. CAMPBELL, op. cit. (n. 1), pl. 57.

49 See the example in room 8 - SH. CAMPBELL, op. cit. (n. 1), pl. 58.

${ }^{50}$ See В.ПОПОВА-МОРОЗ, 24 древни мозайки от България, София, 1987, обр. 20.
} 


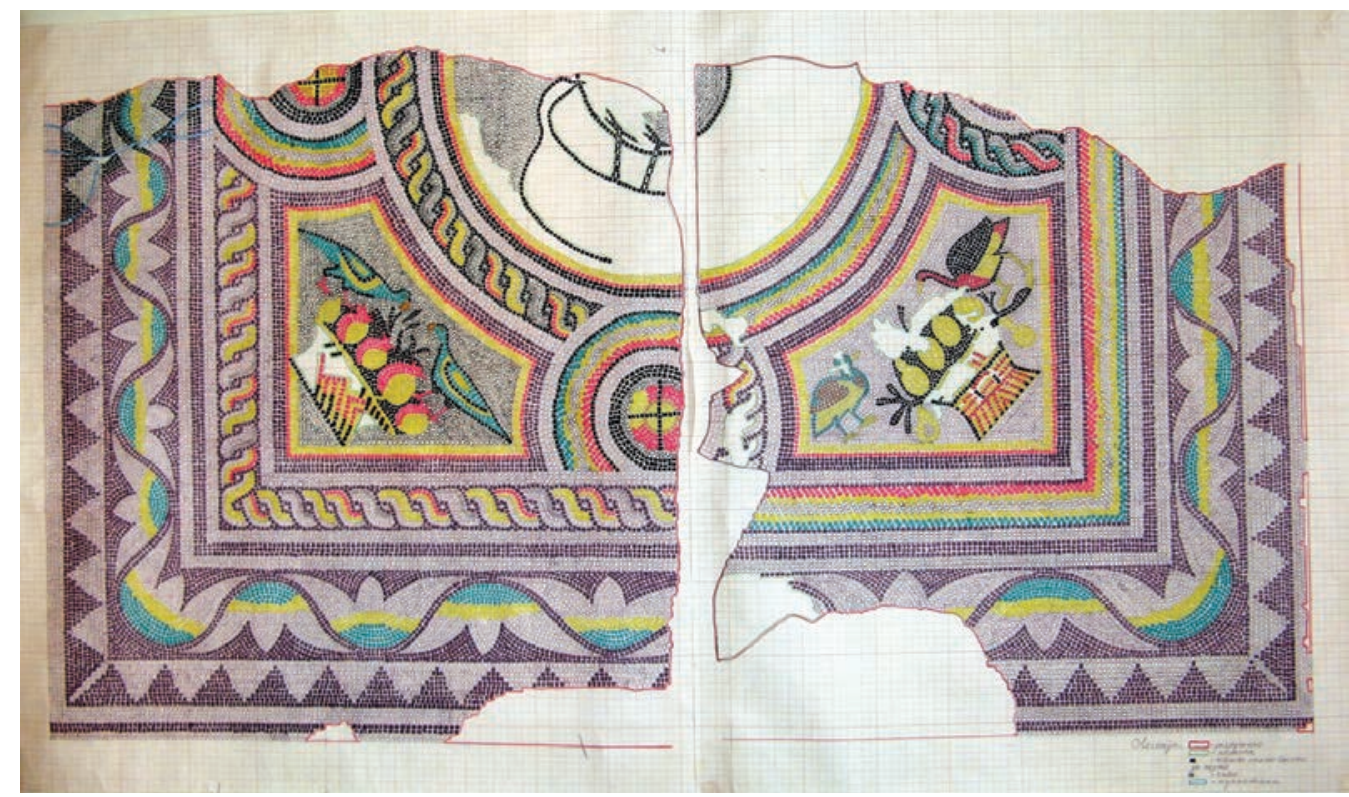

Fig. 14. The mosaic in the triclinium of the so-called 'Residence' (after E. Кесякова, Мозайки от резидениията на Филипопол, Годишник на Регионалния археологически музей-Пловдив, 11, 2009, 153, fig.8)
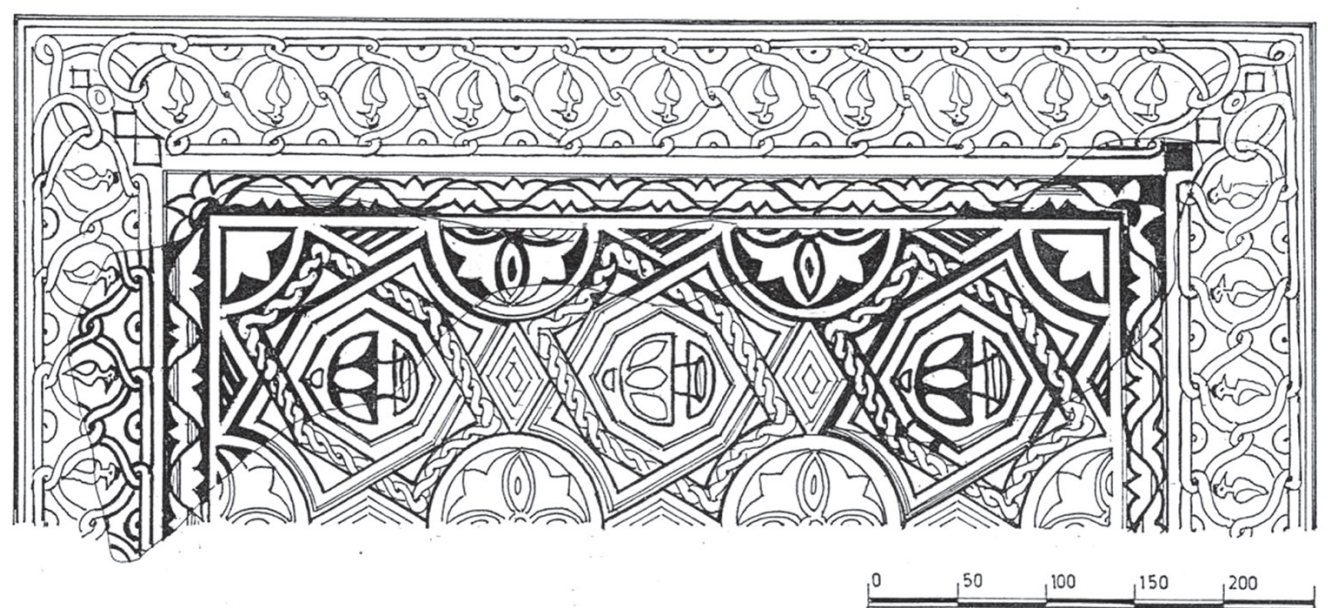

Fig. 15. The mosaic of the Martyrium (after М. Боспачиева, В. Коларова, Пловдив, град върху градовете. Филипопол-Пулпудева-Пълдин), София, 2014, 285)

rene of middle/second half of $5^{\text {th }} \mathrm{c}$. was made by north Greek masters rather than Syrian, following the taste and fashion in Philippopolis. The same is the situation with the other type of rosette with only four leaves. An interesting rosette is the one which is found in room 9 with elongated leaves, for which I haven't found any parallel yet and it makes me believe that we are dealing with a local type.

\section{LOTUSES}

The lotus chalices are to be found in the small triclinium in the so-called Residence of the second half of $5^{\text {th }} \mathrm{c}$. and later in the narrow frame of the central panel of the Maryrium of $6^{\text {th }} \mathrm{c}$. In the first case the lotus is in light blue and yellow with white leaves (fig. 14) while in the Martyrium the chalices are red and the leaves are white..$^{51}$ In Antioch the lotus chalices were used in the bordure of the House of the Buffet Supper of early $3^{\text {rd }} c .^{5^{2}}$ It is true, that this element is used also in the inner frame of the central panel, but with this the similarities come to an end. The differences are to be found in the shape itself, but also in the colour range. Unlike the Antiochenes ones, the lotus chalices from Philippopolis are made in flat shape in contrast to the slender examples from Syria. It is probably due to the elongation of the chalices, which is also underlined by the colours.

As for the colour range, three colours are used in the lotus chalices in the Antiochian mosaics and in the so-called 'Residence' in Philippopolis, but only two in the Martyrium. The differences are also to be observed in the background of the chalices, which is light-yellow in Antioch and white in Philippopolis, but also in the flower itself which is brown and yellow in Antioch and blue and yellow in Philippopolis. There is no doubt that these discrepancies are not in favor of the analogous parallels between them proposed in the literature.

The kantharoi and bordures presented in the mosaic pavement in Philippopolis also did not find exact parallels in shape and colours in the mosaics made in Syrian workshops (fig. 15). In this case, the Syrian influence could be searched

${ }^{51}$ M. BOSPATCHIEVA, op. cit. (n. 32) p. 6o.

${ }^{2}$ See F. CIMOK, op. cit. (n. 1), p. 123 for the mosaic; see also K. DUNBABIN, The Roman Banquet. Images of Conviviality, Cambridge, 2003, p. 160; D. LEVI, op. cit. (n. 1) p. 127-136; House of Buffet Supper: ibidem, pl. 124 and 126. 
in the mosaic of $6^{\text {th }}$ c., which decorated the floor of the martyrium where by colour diversity and use of organic ornaments, viz. birds, in the bordure was contrasted to the black-white central panel. As one may observe, here the specific tendency for the Near East appeared with confrontation of the bordure to the central panel. As a very close parallel to the bordure of the mosaic in the martyrium could be pointed out the one in the mosaic in the narthex of the monastery church St. Martyrius at Ma'ale Adummim, dated from $6^{\text {th }} c .53$ The differences are noticeable in the uniformity of the decoration in Philippopolis, the use only of birds and a geometric frame in the central panel. This shows that no direct link should be found between these examples.

It seems to me unnecessarily to look for more similarities between the mosaics in Philippopolis and Syria in the aspect discussed in this paragraph as even the main elements are different.

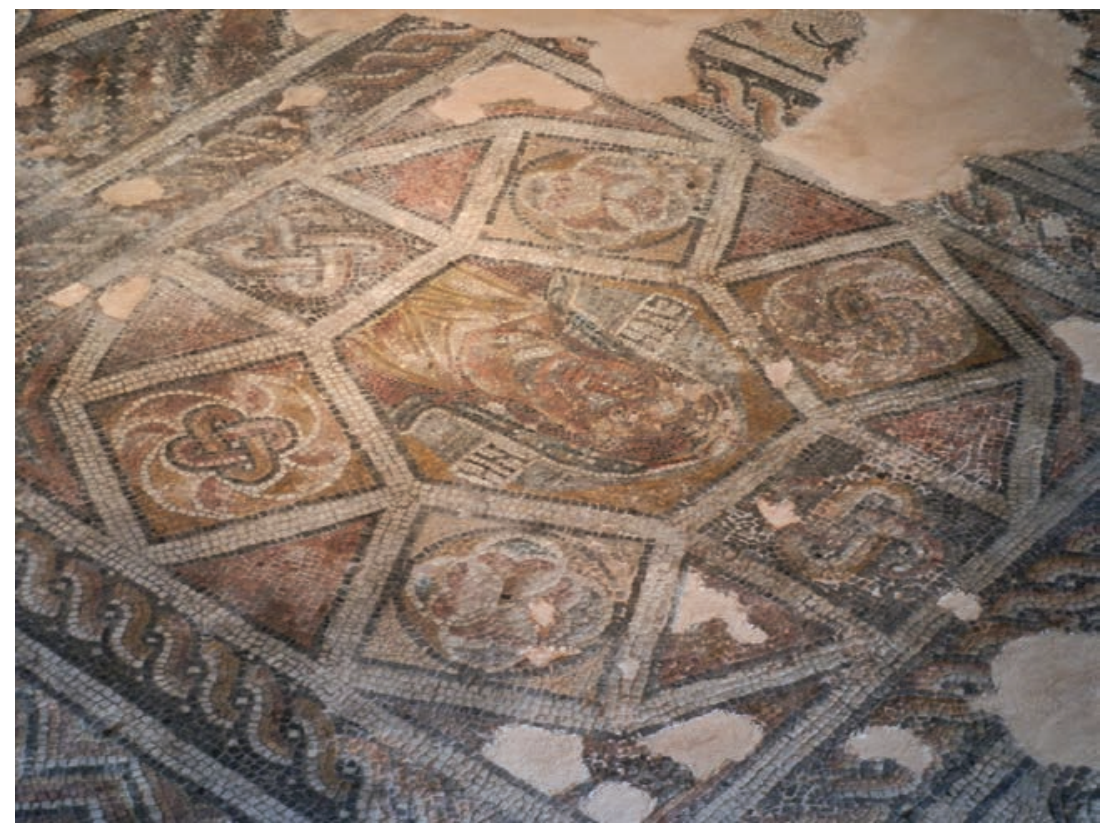

Fig. 16. Domus Eirene, the medallion with the image of Eirene

\section{IMAGES:}

When dealing with certain Syrian parallels of images found in the mosaics in Philippopolis, the mostly discussed image is the image of EIRHNH, which decorated the aula of Domus Eirene (fig. 16). The closest parallel of the EIRHNH image is said to be that of EIRHNH from Halicarnassus, which in fact is only a parallel of the personification, but not the image, and the famous personifications from Syria, ${ }^{54}$ and Cyprus ${ }^{55}$ presented with a human head or bust inside medallions of various shape - circular, square, or polygonal, similar to those found in the mosaics of Antioch, and Apamea are concerned. ${ }^{6}$ In those parallels, however, the personification of Gea and seasons for example are presented in a frame of a geometric scheme of interlocking scuta shields forming lozenges filled with the images (DG pl. 153a). The differences are clearly observed in iconography. The processes that underwent in Syria in the late $4^{\text {th }} \mathrm{c}$. are connected with full geometrisation of the mosaics, ${ }^{57}$ but the final result as clearly observed in the Kaoussie Church is rare until the beginning of $5^{\text {th }} \mathrm{c}$. The rest known examples show that initially the figural images were incorporated in the geometric scheme as it is the case with the mosaic of Gea and Seasons ${ }^{5}$ or by a combination of figural and geometric panels. The latter is found in the synagogue in Apamea.59 It is most likely that this trend reached the western coast of
Asia Minor as early as late $4^{\text {th }}$ - the beginning of $5^{\text {th }} c .^{60}$ and consequently in the geometric scheme appeared floral, and after that organic elements. ${ }^{61}$

The case in Philippopolis seems to be different. As the known examples so far reveal the classical emblemata still existed until the beginning of $5^{\text {th }}$ c. $^{62}$ Certainly, the new trend in the mosaic art was known in the city or at least it was introduced and the idea of eliminating the emblemata is clearly observed in the EIRHNH mosaic itself by making two equal images. The lack of strict geometrisation, which is specific for the Syrian workshops, and reached its culmination in the middle/second half of $5^{\text {th }} \mathrm{c}$. as the mosaic Ananeosis shows is a very distinguished thing.

The division which is observed in EIRHNH mosaic finds an exact parallel with the mosaic from Cos rather than from Syria. Thus, in room 3 in one of the late antique buildings a mosaic floor with the image of the personified Tyche was discovered. The author of the publication is inclined to see in this an example of the so-called Theodosian 'classicism' which still existed in the first half of $5^{\text {th }} c^{63}$ The similarities in the image as well as the compositional idea as a whole between this mosaic and the EIRHNH mosaic in Philippopolis allow me to accept the idea that the master in Philippopolis had Cos origin or he was very influenced by this workshop ${ }^{64}$, rather than Syria. This workshop seems to

\footnotetext{
${ }^{53}$ see Y. MAGEN, The Monastery of St. Martyrius at Ma 'ale Adummim, in: Ancient Churches revealed (ed. V. Tsafaris), Jerusalem, 1995 , p. 179.

${ }^{54}$ M. BOSPACHEIVA, op. cit. ( n. 3) p. 97; M. BOSPAČIEVA, op. cit. (n. 3), 39 with citation of J. BALTY, op. cit. (n. 1) pl. XV).

55 M. BOSPACHEIVA, op. cit. ( n. 3 ) p. 98.

${ }^{56}$ Ibidem, 98.

${ }^{57}$ See E. KITZINGER, Stylistic development in pavement mosaics in the Greek East from the age of Constantine to the age of Justinian, La mosaïque grécoromaine, II, Paris, 1975, $343 \mathrm{ff}$.

${ }_{5}^{8}$ Balty 1995, 347-348, pl. XV, 3; pl. XVI, 1-2 - second half of $4^{\text {th }}$ c.

59 J. BALTY, op. cit (n. 1) p. 73, 89, 350, pl. XVIII,2.

${ }^{60}$ See the example in Aphrodisias and the parallels including that in the Synagogue in Sardi - SH. CAMPBELL, The Mosaics of Aphrodisias in Caria, Subsidia Mediaevalia 18, Toronto, 1991, 19, pl. 58-66.

${ }^{61}$ See E. KITZINGER, op. cit. (n. 57).

${ }^{62}$ See the mosaic published in B. ТАНКОВА, Късноантична мозайка от Филипопол, Археология, 1980, 2, 27-35.

${ }^{6}$ E. BROUSCARI,The Tyche of Cos on a mosaic from a Late Antique house in Cos - in: Patron and Pavements in Late Antiquity (ed. S. Isager and B. Poulsen), Halicarnassian Studies, II, Odense, 1997, 72; fig. 3; pl. 3.

${ }^{64}$ This idea is advanced by V. Popova.
} 
be one of the major workshops in the region, ${ }^{65}$ which as the case in Halicarnassus shows spread over outside the island. It is logical to assume that the mosaic in Philippopolis, if it is not made by a master of this workshop, at least was made by a master influenced by this workshop, which, on the other hand, had undergone a heavily influence by the strong Syrian workshops.

There is also another differentiation between the EIRHNH mosaic and the mosaics in Syria. It deals with the broad bordure which in the EIRHNH mosaic seems to be the third major element along with both images. It surrounded both panels, but also divided them. The northern is $1,5 \mathrm{~m}$ wide while the southern is $1 \mathrm{~m}$ and both are richly decorated by ornaments and colours. ${ }^{66}$ Such a combination of three elements - figural and geometric panels, but also wide bordures was not common in Syria at all. This difference should be taken into account when the study of the mosaic in Philippopolis is made.

This very brief and punctual analysis of some of the most characteristic elements of the mosaic in the Late antique Philippopolis which are believed to be Syrian or made under Syrian influence allows some comments. It should be pointed out that not all of the mosaics from Philippopolis are considered here, and especially those in which the influence of Northern Greek, the local and particularly the Constantinopolitan influence and pattern are clearly observed. Here are discussed only those specific examples which could contribute to the topic.

The analysis presented reveals that there was an undoubtedly strong Syrian influence over the mosaic decoration in Philippopolis. Unlike the thesis which is accepted in the bibliography, however, this influence was not direct, but rather indirect. Until now, no mosaic which copied strictly the Syrian mosaics as it is for example in Cyprus, Jordan, and western Asia Minor is found in Philippopolis. Such absence of clear parallels between the mosaics in Philippopolis and Syria with identical motifs, schemes, images, colours etc. put in question whether Syrian masters worked in Philippopolis at all? The mixture which appears to be in the mosaics in Philippopolis, a mixture from Syrian, East Mediterranean,
Aegean islands and Continental, Northern Greek mosaic workshops and especially from Constantinople is not in favour of Syrian or Eastern masters working in Philippopolis. Where the Syrian influence can be found in composition, patterns, motifs, colours or ornaments, it is combined with such from Constantinople, Northern Greece, Aegean islands. Moreover, some of the 'Syrian' examples in Philippopolis find exact parallel in mosaics in these places, and especially in Constantinople. Thus, in the EIRHNH mosaic Syrian influence is found, but also influence from Cos, in the Episcopal basilica - the influence is Syrian, but mostly metropolitan, in the so-called 'Residence' Syrian and also metropolitan, etc. There is not a single mosaic copying exactly some Syrian type. It seems to me that these cases show the way how the Syrian influence in patterns, motifs, colours, composition etc. entered into Thrace and Philippopolis - via Constantinople, whose workshops seem to have worked all over Thrace or at least the major centers, via northern Greek workshops, and mostly those in Thessalonica, and by the workshops in the Aegean islands. In the prevailing number of cases the Syrian influence, if any, spread over in Thrace and Philippopolis as a synthesis of one of the aforementioned workshops. This can be well illustrated in studying one of the most popular geometric scheme in Philippopolis which is believed to be a direct Syrian influence - namely - DG pl. 144e. ${ }^{67}$ The case that will be studied is situated in room 3 in Domus Eirene.

It is clear that this geometric scheme was found so far only in two cases in Antioch: in room 4 of Bath D dated from AD 300-32568 and the Kaoussie Church of AD 387.69 According to various examples and notably the mosaics in the Synagogue in Sardi, $7^{70}$ the so-called basilica of Ioan ${ }^{71}$ and others in Ephesos, ${ }^{72}$ some of which showing earlier local tradition, ${ }^{73}$ Keramos, ${ }^{74}$ the thermae at Milet ${ }^{75}$ and the socalled temple of Aphrodite in Aphrodisias, Caria, it seems that in the second half of $4^{\text {th }} \mathrm{c}$. the geometric scheme DG pl. 144 e has already reached the western coast of Asia Minor. ${ }^{76}$ From here it spread in two directions: the first one is over the Greek island during the first half/middle of $5^{\text {th }}$ c. such as Karphatos, ${ }^{77}$ Kasos, ${ }^{78}$ Rodos, ${ }^{79}$ Lesbos, ${ }^{80}$ Crete, ${ }^{81}$ Cyprus, ${ }^{82}$

\footnotetext{
${ }_{65}$ On the mosaics of the island of Cos - see recently L. M. DE MATTEIS, Mosaici di Cos. Dagli scavi delle missioni italiane e tedesche (190o-1945), Atene, 2004, (Monografie della scuola archeologica di Atene e delle missioni italiane in Oriente 17).

${ }^{66}$ We should separate here the later alterations which are clearly distinguished in style and colours.

${ }^{67}$ M. BOSPACHEIVA, op. cit. ( n. 3) p. 100.

${ }^{68}$ SH. CAMPBELL, op. cit. (n. 62) p. 15, fig. 8.

69 ibidem, p. 45, pl.133.

$7^{70}$ ibidem, pl. 27; see also V. SCHEIBELREITER-GAIL, Die Mosaiken Westkleinasiens. Tessellate des 2. Jahrhunderts v. Chr. bis Anfang des 7. Jahrhunderts n. Chr., Österreichisches Archäologisches Institut Sonderschriften 46, Wien, 2011, Abb. 526, 578.

${ }^{71}$ V. SCHEIBELREITER-GAIL, op. cit. (n. 72), abb. 184.

${ }^{72}$ Such is the case in the basilica near the Gate in Magnesia dated to late 4th - beginning of 5th c. - V. SCHEIBELREITER-GAIL, op. cit. (n. 72), S. 215-217, Abb. 95; from the gymnasium - ibidem, S. 256-261, Abb. 240-241 (first quarter of 5th c.).

73 See for example House 2 - ibidem, S. 244-246, Abb. 167-168 (third 1/3 of 3rd c.).

74 ibidem, S. 294, Abb. 349.

${ }^{75}$ C. KORANDA, op. cit. (n. 23) S. 86, f. 32; V. SCHEIBELREITER-GAIL, op. cit. (n. 72) Abb. 424.

${ }^{76}$ It is date in late $4^{\text {th }}$ c. - see SH. CAMPBELL, op. cit. (62) p. 9, pl. 24.

77 It is dated in late $4^{\text {th }}$ c. - the beginning of $5^{\text {th }}$ c. - see M. ASSIMAKOPOULOU-ATZAKA, Syntagma ton palaiochristianikon psefidoton dapedon tes

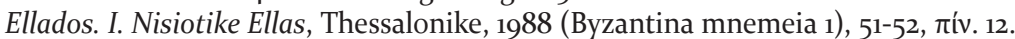

${ }^{8}$ ibidem, 62-63, Tív. $22 \beta$ - 6th c.

79 ibidem, 90, $\pi$ ív. $57 \beta$ - also in the nartex.

80 ibidem, $127-129$, $\pi$ ív. 104 - middle of $5^{\text {th }}$ c.

${ }^{81}$ In Crete - in the middle of $5^{\text {th }}$ c. - ibidem, 109-110, $\pi$ ív. 79; see n. 80.

${ }^{82}$ ibidem, 149, $\pi$ ív. 138 - in the nartex.
} 
and reached Continental Greece. The second way is to Constantinople. In fact, only two examples are known so far from Continental Greece - one in Elis from the second half of $5^{\text {th }}$ c. ${ }^{83}$ and one from Thessaloniki from the first half of $5^{\text {th }} c^{8} .^{84}$ What distinguishes all these examples are the motifs which the mosaic contains. On the one hand, there is a diversity of the motifs, on the other hand, there are cases with only one motif used. Thus, the example from Antioch with guilloche is very close to that of Elis using the same pattern, while in the other cases of this group the lozenge was preferred such as in Ephesos from $3^{\text {rd }}$ c. and Constantinople. ${ }^{85}$ In the next group are the examples with two types of motifs - such as in Sardi, Xantos ${ }^{86}$ and Cypros. The next group consists of diversity of motifs with the use of guilloche, and mostly various geometric ornaments are preferred. These examples derive from Ephesos, including the two basilicas, and mostly from the Aegean islands such as Karpathos, Kasos, Rodos etc. and Thessalonica. This example shows how one of the motifs from Syria can reach Thrace, and the examples may be increased. We should have in mind, however, the local fashion, trend, taste, desires.

Another way is shown in Odessos where, the epigraphic monuments reveal the real presence of a small Syrian group on which the similarities in the mosaics can be based. The masters however, as well as the used material may differ which could explain the differences between the mosaics in Odessos and Syria, and especially the differences in the details; the general frame is accepted, but the details are due to the skill of the local masters and the desire of the local elite. And here is the explanation of the problem - if the decoration of an important building in the home city was not followed, or the decoration of a building in the provincial capital whose mosaics were mostly influenced by Constantinople or made by masters in Constantinople, the idea was transmitted by immigrants and realized by the local masters. The metropolitan influence over Thrace, however, was enormous. It was spread in two ways: the first one is simply copying the decoration of what was in the metropolis by the local patrons and the elite in Thrace and second one - through special imperial policy. And this is clearly visible in the second half of $4^{\text {th }} \mathrm{c}$. at the earliest, but mostly after the decision of Theodosius I to settle in Constantinople. All of a sudden, Thrace from a remote province became part of the hinterland of the metropolis. The economic prosperity of the province as well as the imperial policy made Thrace attractive for many immigrants running from the poverty in Asia Minor. New population is attested not only on the coastal cities such as Odessos, but also in the cities inside Thrace, one of which was the capital of the province - Philippopolis. This is well documented by the funeral stelae found in the necropolises of the city. Thus, we are aware of a certain

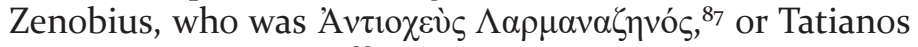
who came from 'Asia'. ${ }^{88}$ In this line is also the inscription

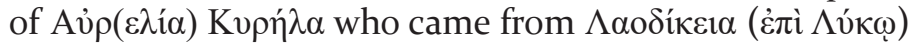
and was $\chi \rho \eta \sigma \tau \iota \alpha v \eta{ }^{89}$ Closer relations between Thrace and Syria were also attested in the religious aspect as the case with Dorotheos shows. It is known that he was a bishop of Antioch with Thracian origin in the time of Valens and in the very beginning of Theodosius I..$^{\circ \circ}$

Despite this evidence, however, the existence of a Syrian community of such a scale as it was in Odessos with its own church built following the Syrian types is not well documented in Philippopolis and very unlikely. Despite the lack of numerous epigraphic monuments, the known ones reveal that some of them existed, and among them there were people with high positions who partly set the taste and trend in the mosaic decoration in Philippopolis; the performance, however, of the mosaics was handled by the local masters or those from the nearest centers. The lack of any concrete full resemblance of motifs and patterns in shape, colours, etc. is not in favour of the assumption that Syrian masters worked in Philippopolis. It is quite on the contrary. It clearly reveals that no Syrian master worked in the city. It is without doubt that Syrian mosaic centers made a great impact in the Near East and Asia Minor, reaching Constantinople and probably Continental Greece and Thessalonica. It is, however, under question if this 'Syrian influence' was Syrian at all or just reflected the Syrian influence through the prism of one of the aforementioned workshops, and especially this in Constantinople. The nature of the similarities and differences found in the mosaics in Philippopolis when compared to those of Syria or impacted by the Syrian tradition gives a great deal of authenticity of such an assumption. And if so, many other examples of this type in Thrace should be reconsidered in this way.

\footnotetext{
$\overline{8_{3}}$ P. ASSIMAKOPOULOU-ATZAKA, Syntagma ton palaiochristianikon psefidoton dapedon tes Ellados. II. Peloponesos-Sterea Hellada, Thessalonike,

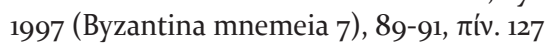

${ }^{84}$ P. ASSIMAKOPOULOU-ATZAKA, op. cit. (n. 15) 253-254, mív. 163-165

${ }^{85}$ It is said that the church which was seriously damaged in AD 404 was restored till 415 - see D. RICE, The Great Palace of the Byzantine Emperors, Edinburgh, 1958, 64; the mosaic is published partly in A. SCHNEIDER, Die Grabung im Westhof der Sophienkirche zu Istanbul, Istanbuler Forchungen 12, 1941, 5, Taf. 12, 1

${ }^{86}$ M.-P. RAYNAUD, Corpus of the Mosaics of Turkey, volume 1. Lycia, Xanthos, Part 1. The East Basilica I, (no year) 78, fig. 79

${ }^{87}$ V. BEŠEVLIEV, Spätgriechische und spätlateinische Inschriften aus Bulgarien, Berlin, 1964, nr. 210

${ }^{88}$ ibidem, nr. 207

89 ibidem, nr. 220

${ }_{90}$ Philostr. HE, 6
} 